ISSN 2077-1827. Гуманізація навчально-виховного процесу. 2019, №. 6 (98)

РОЗДІЛ. ВИЩА ШКОЛА

УДК 378.014.623:37.017.4

\title{
КАРЕЛІН Михайло
}

кандидат педагогічних наук, доцент, доцент кафедри педагогіки вищої школи ДВНЗ «Донбаський державний педагогічний університет», 84116

вул. генерала Батюка, 19, місто Слов’янськ Донецької області, Україна,

E-mail:

\section{НОРЕНКО Марина}

студентка магістерського рівня спеціальності 011 - Освітні, педагогічні науки ДВНЗ «Донбаський державний педагогічний університет», 84116

вул. генерала Батюка, 19, місто Слов’янськ Донецької області, Україна,

E-mail: marynorty@gmail.com

\section{РОЛЬ КУРАТОРА АКАДЕМІЧНОЇ ГРУПИ У ФОРМУВАННІ ГРОМАДЯНСЬКОЇ КУЛЬТУРИ СТУДЕНТСЬКОЇ МОЛОДІ}

Анотація. Авторами статті розкрито роль куратора академічної групи у формуванні громадянської культури студентської молоді. Подано сутність поняття «куратор» за визначенням сучасних науковців. Обгрунтовано систему виховної роботи куратора щодо формування громадянської культури студентської молоді у вищій школі, яка повною мірою розкриває особливості й зміст технології громадянського виховання в освітньому процесі закладу вищої освіти. Схарактеризовано нормативно-правове забезпечення діяльності куратора та виявлено стратегічні завдання виховання справжніх громадян. Проаналізовано обов'язки та виділено функції куратора академічної групи в закладі вищої освіти. Установлено, що робота куратора спрямована на формування національної свідомості, розуміння у студентів сутності соціально-економічних процесів, закономірностей функціонування громадянських цінностей, розвитку індивідуальних якостей особистості, а також на формування вміння вирішувати складні проблеми повсякденного життя, професійної діяльності тощо.

Визначено та розкрито зміст системи виховної роботи як спеціально організованого процесу взаємодії, що впорядковує вплив соціального середовища, суспільних інститутів, окремих суб’єктів, спрямований на надання студентам допомоги у формуванні активної життєвої та громадянської позиції. Доведено, що система виховної роботи куратора академічної групи сприяе інноваційним перетворенням у розбудові громадянського суспільства, оновленню життєвої позиції, розв'язанню комплексу правових, культурно-просвітницьких, педагогічних проблем, пов'язаних із виробленням у студентів якостей, що спонукають особистість до громадянських дій i вчинків Констатовано важливу роль куратора

(C) Карелін М., Норенко М., 2019 
ISSN 2077-1827. Гуманізація навчально-виховного процесу. 2019, №. 6 (98)

РОЗДІЛ. ВИЩА ШКОЛА

академічної групи у формуванні громадянської культури майбутнього фахівця і громадянина своєї держави.

Ключові слова: куратор, інститут кураторства, заклад вищої освіти, функції куратора, виховна система, громадянська культура, патріотизм, громадянська позиція, самовизначення, громадянське суспільство.

Постановка проблеми та її актуальність. Здобуття Україною незалежності, становлення громадянського суспільства створили передумови для розвитку вільної, духовно розвиненої особистості, здатної засвоїти кращі надбання світової та національної духовної спадщини, загальнолюдські культурні цінності. У цьому контексті надзвичайно важливим і невідкладним завданням $є$ виховання справжнього громадянина: активного, освіченого, здатного жити й працювати в умовах демократії, спроможного сприяти соборності й незалежності України, постійно відчувати відповідальність за себе, свій народ і країну.

Відповідно до цього система вищої освіти набуває нового змісту, реалізація якого вимагає генерації нових ідей щодо модернізації процесу громадянського виховання студентів. Розв'язання завдань, що нині постають перед вищою школою, можливе за умови відповідної організації управління системою громадянського виховання студентської молоді, яка суттєво впливатиме на формування особистості майбутнього фахівця як громадянинапатріота, небайдужого до долі української держави, іiі економіки, освіти та культури. Провідна роль в організації ефективної виховної роботи в закладі вищої освіти (далі - 3ВО) належить, безумовно, куратору. Саме від його особистісних якостей і організаторських умінь залежить вектор професійного та особистісного становлення майбутніх фахівців, успіх у формуванні особистості майбутнього професіонала, громадянина, патріота, небайдужого до долі української держави, економіки, освіти, культури тощо.

Аналіз наукових праць, присвячених розв'язанню проблеми. Підгрунтям для визначення ролі куратора академічної групи у процесі формування громадянської культури студентської молоді $\epsilon$ результати сучасних досліджень вітчизняних і зарубіжних учених. Огляд літератури 3 порушеного питання засвідчив, що вивченню проблематики виховання студентів ЗВО присвячено значну кількість наукових праць: цілісність виховного процесу (В. Ортинський), удосконалення системи виховання (Ю. Мельник), особистісно-зорієнтоване виховання (I. Бех), виховання духовної культури студентів (М. Роганова), аналіз виховної діяльності педагога (В. Безпалько, О. Дубасенюк, Г. Троцко), організація виховної роботи у вищих закладах освіти (Г. Пономарьова, С. Сисоєва), духовна культура як цінність (Г. Шевченко); методологічні основи виховання (В.Андрущенко, І. Зязюн, В. Кремень, В. Луговий, Н. Ничкало та ін.), питання технології роботи куратора академічної групи (І. Авдєєва, Н.Гарань, С. Гура, В. Базилевич, Н. Косарева, I. Мельникова, В. Рябченко, В. Сергєєва, О. Сипченко та ін.), педагогічні умови організації позааудиторної виховної роботи у вищих закладах освіти (Т. Куриленко, І.Смирнов, Т. Степура тощо). 
Різним аспектам виховання громадянськості молодого покоління присвячено наукові розвідки Ю. Завалевського, О. Коркішко, М. Кузякіної, К. Пекач, С. Рябова, О. Сухомлинської, К. Чорної та ін. Так, А. Сіговою розглянуто процес формування громадянської позиції студентської молоді, Т.Гребеник досліджено проблему управління процесом громадянського виховання студентів вищих навчальних закладів, В. Шабановим вивчено педагогічні умови успішної громадянської соціалізації студентів.

Аналіз наукової літератури засвідчує посилення уваги науковців до проблем як формування громадянської культури студентської молоді так і до ролі куратора у виховній системі ЗВО. Разом із тим дослідження останніх років (І. Бех, В. Білоусова, Н. Дерев'янко, М. Свтух, В. Кузь, С.Постовойтов, I. Сахневич, В. Струманський та ін.) свідчать, що існує низка протиріч між вимогами, які висуваються до куратора академічної групи, реальним станом його професійної діяльності та можливостями позааудиторної роботи.

Формування цілей статті (постановка завдання). Мета статті полягає у визначенні ролі куратора академічної групи у формуванні громадянської культури студентської молоді.

Виклад основного матеріалу дослідження. Сучасні напрями євроінтеграції, демократизації та модернізації вищої освіти визначають необхідність підготовки висококваліфікованих та конкурентоспроможних фахівців. У першу чергу це стосується формування та розвитку переліку компетентностей у відповідності до обраної спеціальності, а також освіти упродовж життя [1]. Поряд із навчальною діяльністю студентів, яка вважається основним видом діяльності здобувача вищої освіти, у ЗВО паралельно здійснюється процес виховної роботи, за реалізацію якої відповідають куратори академічних груп та заступники декана з виховної роботи. Куратор академічної групи є важливою людиною для студентів, обов'язки якого полягають у створенні позитивного мікроклімату, атмосфери довіри та поваги між студентами академічної групи [2, с. 18].

Доречно вказати, що інститут кураторства 3'явився за часів виникнення навчальних закладів і фактично існує весь час у системі вищої освіти, разом 3 якою зміст його діяльності та характер взаємовідносин зі студентами також набувають нових рис [3]. Термін «куратор» походить від латинського слова «curator» - наставник, піклувальник. Згідно з визначенням А. Ільченко, куратор - викладач, в обов'язки якого входить академічне керівництво студентською групою і позанавчальним життям студентів, забезпечення дотримання студентською групою внутрішньовузівської дисципліни [4]. Ми погоджуємся з Л. Васильєвою, яка довела, що куратор студентської групи це людина, яка здійснює виховну діяльність у вузі, $є$ духовним посередником між суспільством, професією і студентом в засвоєнні загальної і професійної культури, організує систему ціннісних відносин через різноманітні види діяльності студентського колективу, створює умови розвитку кожної особистості, захищає інтереси студентів тощо [5, с. 5].

Зміст діяльності куратора регламентується основними державними документами України, а саме: Законами України «Про освіту», «Про вищу 
ISSN 2077-1827. Гуманізація навчально-виховного процесу. 2019, №. 6 (98)

РОЗДІЛ. ВИЩА ШКОЛА

освіту», Державною національною програмою «Освіта (Україна. XXI століття)», «Концепцією національно-патріотичного виховання дітей та молоді», «Концепцією громадянського виховання особистості в умовах розвитку української державності», «Національною доктриною розвитку освіти України у XXI столітті», а також відповідними інструктивнометодичними документами Міністерства освіти i науки України, положеннями та рекомендаціями, розробленими на рівні закладу освіти.

У цих документах як стратегічні визначаються завдання виховання в особистості любові до Батьківщини, усвідомлення нею свого громадянського обов'язку, формування культури демократії. У концепції «Громадянського виховання особистості в умовах розвитку української державності» зазначається, що громадянське виховання - це «формування громадянськості як інтегративної якості особистості, що дає можливість людині відчути себе морально, соціально, політично та юридично дієздатною та захищеною» [6].

Грунтовне вивчення навчально-методичної літератури, періодичних видань дозволило встановити, що робота куратора академічної групи спрямована на формування національної свідомості, ціннісних орієнтирів $\mathrm{i}$ розвитку індивідуальних якостей особистості, на допомогу студентові в набутті соціального досвіду та поведінки [7, с. 136]. Тож на часі перегляд обов'язків куратора академічної групи в ЗВО. За європейськими освітніми стандартами, куратор сьогодні виконує функції фасилітатора, координатора навчально-виховних дій студента, здійснює духовно-культурний супровід становлення його як особистості, а, отже, є ключовою фігурою суб'єктсуб'єктних стосунків зі студентом в освітньому процесі. У багатьох вітчизняних 3ВО викладач починає наповнювати свою діяльність новим змістом - академічний консультант, тьютор (куратор окремого студента або групи студентів), куратор освітньої програми [8, с. 125]. Аналіз праць [3; 7; 8], присвячених вивченню особливостей діяльності кураторів студентських академічних груп дозволив виділити в роботі куратора наступні функції:

- діагностична, яка забезпечує проведення моніторингу динаміки самовдосконалення, самонавчання, професійного зростання. Реалізуючи діагностичну функцію, куратор виявляє результативність своєї діяльності, визначає напрямки подальшої роботи, спрямованої на формування громадянської культури та розвиток індивідуальності особистості студента;

- прогностична, яка дозволяє визначити рівень сформованості громадянської культури, передбачити проблеми, які можуть постати перед кураторами у процесі здійснення ним виховної роботи;

- посередницька - передбачає встановлення взаємозв'язку у спільній діяльності громадських, соціальних, державних структур для реалізації завдань щодо формування громадянської культури;

- превентивна - дозволяє привести в дію соціально-правові, юридичні, психологічні, соціально-медичні, педагогічні заходи попередження та подолання негативних явищ, надання відповідної допомоги особам, які іiі потребують; 
ISSN 2077-1827. Гуманізація навчально-виховного процесу. 2019, №. 6 (98)

РОЗДІЛ. ВИЩА ШКОЛА

- евристична - сприяє вивченню та впровадженню передового наукового досвіду в роботу куратора щодо формування громадянської культури студентської молоді;

- організаторська - полягає в організації куратором виховних заходів спрямованих на формування громадянської культури студентської молоді, їх попередню підготовку (планування, проектування, якісна реалізація задуму) та проведення;

- аналітична - передбачає аналіз пізнавальної діяльності студентів, рівня їхнього інтелектуального розвитку, індивідуальних особливостей, соціально-побутових умов життя, стану здоров'я, міжособистісних стосунків у колективі, результатів навчання тощо 3 метою подальшого планування та організації виховної роботи щодо формування громадянської культури студентської молоді ;

- комунікативна - дозволяє здійснювати педагогічно доцільне спілкування зі студентською молоддю, спрямована на формування рис справжнього громадянина;

- контролю та корекції - сприяють забезпеченню постійного вдосконалення виховного процесу (функція контролю передбачає виявлення, з одного боку, позитивних результатів, а з іншого - недоліків і проблем, що виникають у процесі виховання; функція корекції - передбачає спільну діяльність куратора і колективу студентської групи або окремих студентів у формуванні громадянської позиції).

Вищезазначене доводить, що у своїй діяльності куратор академічної групи повинен сприяти формуванню в молоді конкретного комплексу особистісних якостей і рис характеру, які у свою чергу формують особливий спосіб мислення та спонукають до повсякденних дій, учинків і поведінки справжнього громадянина:

- патріотична самосвідомість, громадянська відповідальність і мужність, суспільна ініціативність і активність, готовність працювати за для розквіту Батьківщини, захищати іï, підносити міжнародний авторитет;

- повага до Конституції, законів Української держави, прийнятих у ній правових норм, сформована висока правосвідомість;

- досконале знання державної мови, постійна турбота про піднесення іiі престижу і функціонування в усіх сферах суспільного життя і побуту;

- повага до батьків, свого родоводу, до традицій та історії рідного народу, усвідомлення своєї приналежності до нього як його представника, спадкоємця і наступника;

- дисциплінованість, працьовитість, завзятість, творчість, почуття дбайливого господаря своєї землі, піклування про ії природу та екологію;

- фізична досконалість, моральна чистота, висока художньо-естетична вихованість;

- гуманність, шанобливе ставлення до культури, традицій, звичаїв інших народностей, які проживають на території України, високий рівень культури міжнаціонального спілкування (толерантність та полікультурність) $[9$, c. 6]. 
ISSN 2077-1827. Гуманізація навчально-виховного процесу. 2019, №. 6 (98)

РОЗДІЛ. ВИЩА ШКОЛА

Слід наголосити, що сьогодні громадянське виховання розглядається в контексті понять громадянськості, патріотизму, громадянської культури, громадянської позиції, самовизначення, громадянського суспільства, визнання прав і волевиявлень людини, а також громадянської самосвідомості та ідентичності [10, с. 20-21]. Діяльність куратора щодо формування громадянської культури студентської молоді передбачає впровадження грунтовно розробленої дієвої системи виховної роботи, яку ми розуміємо як спеціально організований процес взаємодії, що впорядковує вплив соціального середовища, суспільних інститутів, окремих суб'єктів, спрямований на надання студентам допомоги у формуванні активної життєвої та громадянської позиції [7, с. 134]. Отже, активна життєва і громадянська позиція має стати характерною ознакою випускника сучасної вищої школи.

Успішне вирішення означених завдань вимагає від куратора академічної групи різноманітних форм i методів колективної та індивідуальної виховної роботи: виховні години, бесіди, дискусії, тематичні вечори, творчі зустрічі, культпоходи, екскурсії тощо [11]. Однією з основних форм виховної роботи кураторів $\epsilon$ кураторські години, які можуть проводитися у вигляді бесід, круглих столів, дискусійних клубів, інших заходів виховного впливу в студентських аудиторіях i гуртожитках; подорожами історичними місцями рідного краю; індивідуальна виховна робота зі студентами з урахуванням їхніх особистісних якостей. Кураторські години у вищій школі - це спосіб спілкування викладача й студента, що передбачає вирішення низки виховних завдань, 3-поміж яких важливе місце належить громадянському вихованню.

Виховні заходи - це одна 3 форм залучення студентів до продуктивної діяльності, вони вирізняються масштабністю та числом учасників, 3-поміж яких $\epsilon$ як представники студентської молоді, так i члени громадських організацій. Наприклад: «Україна - європейська держава», «Я - громадянин української держави», «Найкраще - дітям» тощо.

Дискусія - основний метод, що лежить в основі проведення диспуту. Працюючи над проблемою формування громадянської культури, студентам пропонуються такі теми для проведення дискусії: «Молодіжна політика держави: сучасні механізми реалізації», «Моє майбутнє в Україні», «Студентська молодь й політичні процеси», «Що таке демократія?».

3 метою формування громадянської культури студентів куратор організовує ділові ігри: «Державний устрій: реалії сьогодення і погляд у майбутнє», «Сучасне українське суспільство очима молоді», «Я - громадянин незалежної України!», «Як би я став президентом», «Я - прем’єр-міністр». Під час їх проведення формується політична i правова культура, громадянська самосвідомість, життєва позиція тощо. Студенти вчаться висловлювати власну думку, відстоювати іiі в процесі дискусії. Окрім того такі ділові ігри вимагають відповідних знань, широкого кругозору. Для участі у проведенні ділових ігор запрошуються науковці, громадські діячі, відомі люди тощо.

Безумно цікавою формою роботи $\epsilon$ зустрічі студентів зі представниками вчительських династій, учителями-новаторами, учителями- 
методистами, учителями-переможцями в номінаціях «Учитель року», «Кращий класний керівник» тощо. На таких зустрічах студенти знайомляться не тільки $з$ передовим педагогічним досвідом, але вони усвідомлюють красу педагогічної праці, дотикаються сокровенних струн учительського серця. Тож куратор групи вдало використовує виховний потенціал таких зустрічей, формуючи під час їх проведення активну громадянську позицію, громадянську культуру майбутніх учителів і в цілому справжніх громадян української держави.

Традиційними для куратора групи є тематичні свята, на яких студенти вшановують пам'ять героїв своєї держави, пам'ять тих, хто загинув в ім'я Батьківщини, відстоюючи іiі незалежність і свободу. Також цікавими $\epsilon$ традиційні виховні години «Чуття єдиної родини», на яких студенти вчаться позитивно ставитися один до одного, поважати людей різних за соціальним статусом, політичними поглядами, за віросповіданням тощо. Студенти мають усвідомити, кожен 3 них - невід'ємна i неповторна частка нашого суспільства, яка вимагає одна від одної поваги і уваги, шанування і любові, піклування і дбайливого ставлення. На таких заходах під час зустрічі 3 цікавими людьми, представниками різних національностей, наслідувачами різних культур формується відчуття єдності і причетності до всього, що відбувається в сучасному суспільстві. Студенти мають усвідомити, а куратор у цьому допомогти, що кожен із них сам $\epsilon$ творцем свого життя, свого особистого устрою. Здобутки суспільства, його комфортність залежать від кожного з нас, від того, що саме «Я» зробив за для нього. Саме такі виховні заходи без сумніву будуть сприяти формуванню громадянської культури нинішніх студентів, а завтрашніх громадян - активних будівників громадянського суспільства, патріотів своєї країни.

Висновки. Грунтовний аналіз проблеми формування громадянської культури студентської молоді у виховній роботі куратора дозволяє вказати на ii актуальність і перспективність. У ході дослідження встановлено, що діяльність куратора академічної групи спрямована на розуміння у студентів сутності соціально-економічних процесів, закономірностей функціонування громадянських цінностей, а також на формування вміння вирішувати складні проблеми повсякденного життя, професійної діяльності тощо. Звідси виходить, що головною метою діяльності куратора щодо формування громадянської культури $є$ сприяння самопізнанню i самовихованню, творчому саморозвитку особистості кожного студента, яка поєднує загальну i професійну культуру, людську гідність, громадянську позицію і патріотизм, самостійність і відповідальність, працездатність і працьовитість.

У контексті обраної проблеми дослідження нами доведено, що система виховної роботи куратора академічної групи сприяє інноваційним перетворенням у розбудові громадянського суспільства, оновленню життєвої позиції, розв'язанню комплексу правових, культурно-просвітницьких, педагогічних проблем, пов'язаних із виробленням у студентів якостей, що спонукають особистість до громадянських дій i вчинків. Вищезазначене дозволяє констатувати, що куратор академічної групи відіграє важливу роль у 
ISSN 2077-1827. Гуманізація навчально-виховного процесу. 2019, №. 6 (98)

РОЗДІЛ. ВИЩА ШКОЛА

формуванні громадянської культури майбутнього фахівця і громадянина своєї держави. Перспективи подальших розвідок убачаємо у висвітленні досвіду виховної діяльності кураторів у закладах вищої освіти України.

\section{СПИСОК ВИКОРИСТАНОЇ ЛІТЕРАТУРИ}

1. Сипченко О., Черкашина Л., Гарань Н. Формування загальних компетентностей майбутніх викладачів засобами інноваційних технологій в освітньому середовищі ЗВО. Професіоналізм педагога в умовах освітніх інновацій : монографія [за заг.ред. Л.Г. Гаврілової]. Hameln, Germany : InterGING. - 2019. - C. 180-195.

2. Буяльська Т.Б., Прищак М.Д., Мацко Л.А. Робота кураторів академічних груп у вищому навчальному закладі. - Вінниця: ВНТУ, 2010. - 154 c.

3. Романова С.В. Організаційно-виховна робота куратора академічної групи у вищих технічних навчальних закладах : автореф. дис. канд. пед. наук. - Луганськ. - 2006. - 20 с.

4. Ільченко А.А. Діяльність куратора на етапі адаптації студентів у вищому навчальному закладі. Педагогічні науки: зб. наук. праць [Херсонського державного університету]. - 2017. - Вип. 75(2). - С. 3943.

5. Васильева Л.М. Педагогические условия повышения квалификации кураторов студенческой группы в колледже: автореф. дис....канд. пед.наук. -Ставрополь, 2004. - 23 с.

6. Концепція громадянського виховання особистості в умовах розвитку української державності. Шлях освіти. - 2000. - № 3. - С. 7-13.

7. Sypczenko W., Sypczenko O. Praca kuratora w celu kształtowania obywatelskości wśród młodzieży studenckiej. Wychowanie dzieci $i$ młodzieży w społeczeństwie demokratycznym. - Warszawa, 2013. - C. 132-144.

8. Лучанінова П. Куратор академічної групи як ключовий суб'єкт виховної системи ВТНЗО. Духовність особистості: методологія, теорія i практика / [гол. редактор Г.П. Шевченко]. - Вип. 1(76) Сєвєродонецьк: вид-во СНУ ім. В. Даля, 2017 - С. 120-132.

9. Ігнатенко П.Р. Виховання громадянина : психолого-педагогічний i народознавчий аспекти : навч.-метод. посіб. / [П.Р. Ігнатенко, В.Л. Поплужний, Н. І. Косарєва, Л.В. Крицька]. - К. : ІЗМН, 1997. - 249 с.

10. Козлова О.Г., Гребеник Т.В. Керівництво громадянським вихованням студентської молоді : навч.-метод. посіб. - Суми : Університетська книга, 2010. - 188 с.

11.Гарань Н., Осміченко А. Куратор - наставник студентської академічної групи закладу вищої освіти. Гуманізація навчально-виховного процесу : зб. наук. праць / [за заг. ред. проф. В. І. Сипченка]. - Слов’янськ, 2018. - Вип.№ 5 (91). - С. 68-84.

Стаття надійшла до редакції 15.11.2019. 
ISSN 2077-1827. Гуманізація навчально-виховного процесу. 2019, №. 6 (98)

РОЗДІЛ. ВИЩА ШКОЛА

КАРЕЛИН Михаил

кандидат педагогических наук, доцент, доцент кафедры педагогики высшей школы ГВУЗ «Донбасский государственный педагогический университет»,

ул. генерала Батюка, 19, г. Славянск, Донецкой области, Украина, 84116

E-mail:m karelin@ukr.net

\section{НОРЕНКО Марина}

студентка специальности 011 - Образовательные, педагогические науки ГВУЗ «Донбасский педагогический университет»,

ул. генерала Батюка, 19, г. Славянск, Донецкой области, Украина, 84116

E-mail: marynorty@gmail.com

\section{РОЛЬ КУРАТОРА АКАДЕМИЧЕСКОЙ ГРУППЫ В ФОРМИРОВАНИИ ГРАЖДАНСКОЙ КУЛЬТУРЫ СТУДЕНЧЕСКОЙ МОЛОДЕЖИ}

Резюме. Авторами статьи определена роль куратора академической группы в формировании гражданской культуры студенческой молодежи. Подана сущность понятия «куратор» по определению современных ученых. Обоснована система воспитательной работы куратора по формированию гражданской культуры студенческой молодежи в высшей школе, раскрыты особенности и содержание технологии гражданского воспитания в образовательном процессе учреждения высшего образования. Охарактеризовано нормативно-правовое обеспечение деятельности куратора и выявлены стратегические задачи воспитания настоящих граждан. Проанализированы обязанности и выделены функции куратора академической группы в учреждении высшего образования. Установлено, что работа куратора направлена на формирование национального сознания, ценностных ориентиров и развития индивидуальных качеств личности. Определено и раскрыто содержание системы воспитательной работы как специально организованного процесса взаимодействия, который упорядочивает влияние социальной среды, общественных институтов, отдельных субъектов, направленный на предоставление студентам помощи в формировании активной жизненной и гражданской позиции. Доказано, что система воспитательной работы куратора академической группы способствует инновационным преобразованиям в развитии гражданского общества, обновлению жизненной позиции, решению комплекса правовых, культурно-просветительских, педагогических проблем, связанных с выработкой у студентов качеств, побуждающих личность к гражданским действиям и поступкам. Констатирована важная роль куратора академической группы в формировании гражданской культуры будущего специалиста и гражданина своего государства.

Ключевые слова: куратор, институт кураторства, учреждение высшего образования, функции куратора, воспитательная система, гражданская культура, патриотизм, гражданская позиция, самоопределение, гражданское общество. 


\section{KARELIN Mykhailo}

Candidate of Pedagogical Sciences, Associate Professor of the Chair of Pedagogics of Higher School, SHEI "Donbas State Pedagogical University",

General Batyuk Str., 19, Slovyansk, Ukraine, 84116

E-mail:m_karelin@ukr.net

\section{NORENKO Maryna}

Specialty student 011 - Educational and pedagogical sciences of the SHEI "Donbas State Pedagogical University",

General Batyuk Str., 19, Slovyansk, Ukraine, 84116

E-mail: marynorty@gmail.com

\section{THE ROLE OF THE CURATOR OF ACADEMIC GROUP IN THE FORMATION OF CIVIL STUDENT CULTURE}

Summary. Solving the tasks which now stand before the higher school, subject to the relevant management system of civil education of students significantly influence the formation of personality of a future specialist as a citizen-patriot, not indifferent to the fate of the Ukrainian state, its economy, education and culture. The leading role in the organization of effective educational work in the higher education institution, of course, belongs to the curator. The above suggests that the academic group's curator plays an important role in shaping the civic culture of the future specialist and citizen of his or her state.

Keywords: curator, institute of curating, higher education institution, functions of curator, educational system, civil culture, patriotism, civil position, self-determination, civil society.

Abstract. Introduction. The modern system of higher education acquires a new content, realization of which requires the generation of new ideas for the modernization of process of civil education of students. Solving the tasks which now stand before the higher school, subject to the relevant management system of civil education of students significantly influence the formation of personality of a future specialist as a citizen-patriot, not indifferent to the fate of the Ukrainian state, its economy, education and culture. The leading role in the organization of effective educational work in the higher education institution, of course, belongs to the curator. His personal qualities and organizational skills depends on the vector of professional and personal formation of future specialists, the success in shaping the personality of the future professional, citizen, patriot, not indifferent to destiny of the Ukrainian state, economy, education, culture, etc.

Analysis of publications. The basis for determining the role of the curator of the academic group in the process of forming the civic culture of student youth are the results of modern studies of domestic and foreign scientists ( I. Avdeev, V. Andrushchenko, V. Bezpalko, I. Bech, N. Garan, O. Dubaseniuk, I. Ziazun, V. Kremen, T. Kurilenko, V. Lugovyi, N. Nichkalo, V. Ortinsky, G. Ponomaryova, M. Roganova, S. Sisoeva, I. Smirnov, G. Trotsko, G. Shevchenko; S. Gura, V. Basilevich, N. Kosareva, I. Melnikova, V. Ryabchenko, V. Sergeeva, O. Sypchenko, T. Stepura. 
Purpose. The purpose of the article is to determine the role of the curator of the academic group in shaping the civic culture of student youth.

Results. In the state documents of Ukraine, as strategic are defined the tasks of education in the personality of love for the Motherland, awareness of its civic duty, the creation of a culture of democracy. Civic education is the formation of citizenship as an integrative quality of personality that enables a person to feel morally, socially, politically, and legally capable and protected."

The work of the curator of the academic group focused on the formation of national consciousness, values and the development of individual personality traits, to help the student in the acquisition of social experience and behavior. Analysis of works devoted to the study of the peculiarities of curators' activities of student academic groups allowed us to highlight the work of the curator the following functions: diagnostic, prognostic, mediation, preventative, heuristic, organizational, analytical, communication, control and correction.

Conclusion. The study found that the activities of the curator of academic group is aimed at understanding the students of the essence of socio-economic processes, patterns of functioning of civic values, as well as the formation of the ability to solve complex problems of daily life, professional activity, etc. It turns out that the main purpose of the activity of the curator on the formation of civic culture is to promote self-knowledge and self-education, creative self-development of each student's personality, which combines common and professional culture, human dignity, civic position and patriotism, independence, responsibility, efficiency and diligence. In the context of the chosen research problem, we have been proved that the educational system of the curator of academic group promotes innovative transformations in the development of civil society, the renewal of life position, the solution of the complex of legal, cultural and educational, pedagogical problems related to the development of students' qualities, inspire the individual to civic actions and deeds. The above suggests that the academic group's curator plays an important role in shaping the civic culture of the future specialist and citizen of his or her state.

\section{REFERENCES}

1. Sypchenko O., Cherkashina L., Garan N. (2019) Formation of general competencies of future teachers by means of innovative technologies in the educational environment of ZVO. Professionalism of the teacher in the context of educational innovations : Edited by Dr. hab. in Pedagogics, Professor Lyudmyla Havrilova. - Hameln, Germany : InterGING. - P. 180195. [in Ukrainian].

2. Buyalska T.B., Pryshchak M.D., Matsko L.A. (2010) Work of curators of academic groups in higher education. - Vinnytsia: VNTU. - 154 p. [in Ukrainian].

3. Romanova S.V. (2006) Organizational and educational work of the curator of the academic group in higher technical educational establishments: abstract of the dissertation of the candidate of pedagogical sciences. Lugansk. -20 p. [in Ukrainian]. 
4. Ilchenko A.A. (2017) The activity of the curator at the stage of adaptation of students in higher education. Pedagogical Sciences: Zb. nauk. prats [Kherson State University]. \#75(2). - P. 39-43. [in Ukrainian].

5. Vasilieva L.M. (2004) Pedagogical conditions for advanced training of curators of a student group in college: abstract of the dissertation of the candidate of pedagogical sciences. - Stavropol. -23 p. [in Russian].

6. The concept of civic education of the individual in the conditions of development of the Ukrainian statehood (2000). Way of education. \#3. - P. 7-13. [in Ukrainian].

7. Sypczenko W., Sypczenko O. (2013) Praca kuratora w celu kształtowania obywatelskości wśród młodzieży studenckiej. Wychowanie dzieci $i$ mtodzieży w spoleczeństwie demokratycznym. - Warszawa. - P. 132-144. [in Ukrainian].

8. Luchaninova P. (2017) Curator of the academic group as a key subject of the educational system of the Higher Education Institute. Personality spirituality: methodology, theory and practice / [Editor-in-Chief G.P. Shevchenko]. \#1 (76) - Severodonetsk: V. Dahl University Press. - P. 120132. [in Ukrainian].

9. Ignatenko P.R. (1997) Education of the Citizen: Psychological-Pedagogical and Ethnological Aspects: A Training Manual / [P.R. Ignatenko, V.L. Popluzhnyi, N.I. Kosareva, L.V. Crecka]. - K. : IZMN. - 249 p. [in Ukrainian].

10.Kozlova O.G., Grebenik T.V. (2010) Guide to civic education of student youth: A Training Manual. - Sums: University Book. - 188 p. [in Ukrainian].

11. Garan N., Osmichenko A. (2018) Curator - mentor of the student academic group of higher education institution. Humanization of the educational process : Zb. nauk. prats. / [za zag. red. prof. V.I. Sypchenka]. Slov'yansk. \#5 (91). - P. 68-84. [in Ukrainian].

(переклад на англійську мову зробено Л. Погорєловою - учителем іноземної мови і зарубіжної літератури). 